Article

\title{
Anthraquinone Derivatives from a Marine-Derived Fungus Sporendonema casei HDN16-802
}

\author{
Xueping Ge ${ }^{1}$, Chunxiao Sun ${ }^{1}$, Yanyan Feng ${ }^{1}$, Lingzhi Wang ${ }^{1}$, Jixing Peng ${ }^{3}$, Qian Che ${ }^{1}$, \\ Qianqun Gu ${ }^{1}$, Tianjiao Zhu ${ }^{1,2}(\mathbb{D})$, Dehai Li ${ }^{1,2}$ (D) and Guojian Zhang 1,2,*(D) \\ 1 Key Laboratory of Marine Drugs, Chinese Ministry of Education, School of Medicine and Pharmacy, Ocean \\ University of China, Qingdao 266003, China; 15610568273@163.com (X.G.); sunchunxiao93@163.com (C.S.); \\ yy15715321143@163.com (Y.F.); wlz8866wlz@163.com (L.W.); cheqian064@ouc.edu.cn (Q.C.); \\ guqianq@ouc.edu.cn (Q.G.); zhutj@ouc.edu.cn (T.Z.); dehaili@ouc.edu.cn (D.L.) \\ 2 Laboratory for Marine Drugs and Bioproducts of Qingdao National Laboratory for Marine Science and \\ Technology, Qingdao 266237, China \\ 3 Key Laboratory of Testing and Evaluation for Aquatic Product Safety and Quality, Ministry of Agriculture \\ and Rural Affairs, Yellow Sea Fisheries Research Institute, Chinese Academy of Fishery Sciences, \\ Qingdao 266071, China; pengixing1987@163.com \\ * Correspondence: zhangguojian@ouc.edu.cn; Tel.: +86-532-82032065
}

Received: 30 April 2019; Accepted: 29 May 2019; Published: 4 June 2019

\begin{abstract}
Five new anthraquinone derivatives, auxarthrols D-H (1-5), along with two known analogues (6-7), were obtained from the culture of the marine-derived fungus Sporendonema casei. Their structures, including absolute configurations, were established on the basis of NMR, HRESIMS, and circular dichroism (CD) spectroscopic techniques. Among them, compound 4 represents the second isolated anthraquinone derivative with a chlorine atom, which, with compound $\mathbf{6}$, are the first reported anthraquinone derivatives with anticoagulant activity. Compounds $\mathbf{1}$ and $\mathbf{3}$ showed cytotoxic activities with $\mathrm{IC}_{50}$ values from $4.5 \mu \mathrm{M}$ to $22.9 \mu \mathrm{M}$, while compounds 1, 3-4, and 6-7 showed promising antibacterial activities with MIC values from $12.5 \mu \mathrm{M}$ to $200 \mu \mathrm{M}$. In addition, compound 7 was discovered to display potential antitubercular activity for the first time.
\end{abstract}

Keywords: anthraquinone derivatives; Sporendonema casei; marine-derived fungus; cytotoxic activities; antibacterial activities

\section{Introduction}

Anthraquinones and their derivatives are a group of pigmented polyketides widely produced by fungi. Apart from their bright color attributed to the typical conjugate system in their structure, they have also attracted the attention of scientists due to their diversity of structures and wide range of pharmacological effects, such as their anti-infective, anti-inflammatory, and $\alpha$-glucosidase inhibitory activities and cytotoxicity against cancer cells [1,2]. Following the discovery of altersolanol A reported in 1967 [3], a series of anthraquinone derivatives have been discovered from various fungal genera, including Alternaria [4,5], Streptomyces [6,7], Dactylaria [8], Bostryconema [9], Stemphylium [10], Pleospora [11], Auxarthron [12], Ampelomyces [13], Nigrospora [14], and Phomopsis [15].

During our exploration of novel bioactive secondary metabolites obtained from marine-derived microorganisms, a fungus Sporendonema casei HDN16-802 isolated from a sediment sample collected from Zhangzi Island was selected due to its special morphological characteristic (orange color) and tremendous metabolic profile identified via HPLC-UV. Further chemical study generated five new anthraquinones, named auxarthrols D-H (1-5), along with two known analogues (6-7). To the best of our knowledge, this is the first time that anthraquinone derivatives have been isolated from the fungus $S$. casei. The cytotoxicity, antibacterial, anticoagulant, and antitubercular activities of 1-7 were 
tested. Herein, we will describe the isolation, structural elucidation, and biological activities of the isolated compounds.

\section{Results and Discussion}

Sporendonema casei HDN16-802 was cultured (45 L) under static conditions with oatmeal medium at room temperature for one month. The fermentation product (mycelium and broth) was extracted with ethyl acetate to provide the crude extract $(10 \mathrm{~g})$. The crude extract was fractionated by different kinds of chromatography, including silica gel vacuum liquid chromatography (VLC), C-18 column chromatography (ODS), Sephadex LH-20 column chromatography, medium performance liquid chromatography (MPLC), and finally HPLC to yield $\mathbf{1}(10.0 \mathrm{mg}), \mathbf{2}(2.1 \mathrm{mg}), \mathbf{3}(5.1 \mathrm{mg}), \mathbf{4}(5.0 \mathrm{mg}), \mathbf{5}$ (4.5 mg), 6 (10.1 mg), and 7 (5.0 mg) (Figure 1).<smiles>COc1cc(O)c2c(c1)C(=O)[C@@]1(O)[C@@H](O)[C@@H](O)[C@@H](O)[C@](C)(O)C[C@]21O</smiles><smiles>COc1cc(O)c2c(c1)C(=O)[C@@]1(Cl)[C@@H](O)[C@@H](O)[C@@](C)(O)C[C@]1(O)C2=O</smiles>

4<smiles>COc1cc(O)c2c(c1)[C@H](O)[C@]1(O)C[C@@H](O)[C@@H](O)[C@H](O)[C@]1(O)C2=O</smiles>

2<smiles>COc1cc(O)c2c(c1)[C@H](O)[C@@]13C[C@](C)(O)[C@@H](O)[C@@H](O)[C@]1(O3)C2=O</smiles><smiles>COc1cc(O)c2c(c1)C(=O)[C@@]1(O)[C@H](O)[C@H](O)[C@@](C)(O)C[C@]1(O)[C@H]2O</smiles>

3<smiles>[R]C1C2=C(C[C@](C)(O)[C@@H]1O)C(=O)c1cc(OC)cc(O)c1C2=O</smiles>

Figure 1. Structures of 1-7.

Compound 1 was isolated as a pale yellow solid with the molecular formula $\mathrm{C}_{16} \mathrm{H}_{18} \mathrm{O}_{8}$, which was established on the basis of the (+)-HRESIMS ion peak at $\mathrm{m} / \mathrm{z} 339.1076[\mathrm{M}+\mathrm{H}]^{+}$and $\mathrm{m} / \mathrm{z} 361.0897$ $[\mathrm{M}+\mathrm{Na}]^{+}$, indicating eight degrees of unsaturation. The 1D NMR $\left({ }^{1} \mathrm{H}-\mathrm{NMR},{ }^{13} \mathrm{C} \mathrm{NMR}\right.$, and DEPT $)$ spectrum (Tables 1 and 2 and Supplementary Materials), together with HSQC correlations (Figure S5), provided five hydroxyl protons, including a chelated hydroxyl at $\delta_{\mathrm{H}} 12.44(\mathrm{~s})$; two methyls, including one methoxy $\left(\delta_{\mathrm{H}} 3.87, \mathrm{~s} ; \delta_{\mathrm{C}} 56.7\right)$; one methylene $\left(\delta_{\mathrm{H}}, 1.86, \mathrm{~m} ; \delta_{\mathrm{C}} 34.2\right)$; five methines, including two meta-coupled aromatic $s p^{2}$ methines $\left[\delta_{\mathrm{H}} 6.79, \mathrm{~d}(2.4), \delta_{\mathrm{C}} 106.1 ; \delta_{\mathrm{H}} 6.83, \mathrm{~d}(2.4), \delta_{\mathrm{C}} 105.0\right]$ and two $s p^{3}$ oxygenated methines $\left[\delta_{\mathrm{H}} 3.61\right.$, dd $(5.7,3.1), \delta_{\mathrm{C}} 73.7 ; \delta_{\mathrm{H}} 4.22$, dd $\left.(4.5,3.1), \delta_{\mathrm{C}} 71.3\right]$; and eight non-protonated carbons, including two conjugated ketones $\left(\delta_{C} 197.3\right.$ and 200.1), four aromatic carbons $\left(\delta_{C} 166.1,166.3,110.1\right.$, and 137.6$)$, and two oxygenated quaternary $\left(\delta_{C} 72.3\right.$ and 78.2$)$ carbons. A careful comparison of the above signals with those of the known compound auxarthrol B [12] revealed a very similar hydroanthraquinone skeleton, while the most significant differences were the absence of a hydroxyl group and the appearance of a methine signal $\left[\delta_{\mathrm{H}} 3.36, \mathrm{~m} ; \delta_{\mathrm{C}} 48.0\right]$ attributed to C-1a (Table 2). The key HMBC correlations from H-1a to C-9 and C-2 (Figure 2 and Supplementary Materials) further confirmed the planar structure of $\mathbf{1}$. 
Table 1. ${ }^{1} \mathrm{H}$ NMR data of compounds $\mathbf{1 - 5}(500 \mathrm{MHz}, \mathrm{TMS}, \delta \mathrm{ppm}, J$ in $\mathrm{Hz}$ ).

\begin{tabular}{|c|c|c|c|c|c|c|}
\hline No. & $1^{a}$ & $2^{a}$ & $2^{b}$ & $3^{a}$ & $4^{a}$ & $5^{a}$ \\
\hline 1 & $1.86, \mathrm{~m}$ & $\begin{array}{l}\text { 1.92, d (14.6); } \\
1.83 \text {, d (14.6) }\end{array}$ & $\begin{array}{l}\text { 1.92, d (14.6); } \\
1.83, \mathrm{~d}(14.6)\end{array}$ & $\begin{array}{l}\text { 1.82, d (14.2); } \\
1.75, \mathrm{~d}(14.2)\end{array}$ & $\begin{array}{l}\text { 2.24, d (14.8); } \\
\text { 1.74, d (14.8) }\end{array}$ & $\begin{array}{l}\text { 2.35, dd (15.5); } \\
\text { 2.31, dd (15.5) }\end{array}$ \\
\hline 3 & 3.61, dd $(5.7,3.1)$ & $3.57, \mathrm{~d}(3.0)$ & $3.57, \mathrm{~m}$ & $3.46, t(3.0)$ & $3.61, \mathrm{~d}(3.6)$ & $3.46, \mathrm{~d}(3.7)$ \\
\hline 4 & $4.22, \mathrm{dd}(4.5,3.1)$ & $4.43, \mathrm{~d}(3.0)$ & $4.43, \mathrm{t}(3.5)$ & $4.39, \mathrm{dd}(3.0,9.7)$ & $4.69, \mathrm{~d}(3.6)$ & $4.57, \mathrm{~d}(3.7)$ \\
\hline 6 & $6.79, \mathrm{~d}(2.4)$ & $6.35, \mathrm{~d}(2.5)$ & $6.35, \mathrm{~d}(2.5)$ & $6.34, \mathrm{~d}(2.4)$ & $6.82, \mathrm{~d}(2.5)$ & $6.42, \mathrm{~d}(2.4)$ \\
\hline 8 & $6.83, \mathrm{~d}(2.4)$ & $6.64, \mathrm{~d}(2.5)$ & $6.64, \mathrm{~m}$ & 6.67, d (2.4) & $6.96, \mathrm{~d}(2.5)$ & $6.67, \mathrm{dd}(2.4,1.2)$ \\
\hline 9 & & $4.73, \mathrm{~s}$ & $4.73, \mathrm{~d}(9.5)$ & $4.52, \mathrm{~d}(8.7)$ & & $4.83, \mathrm{~d}(1.2)$ \\
\hline $1 \mathrm{a}$ & $3.36,(6.0,1.5)$ & & & & & \\
\hline $4 a$ & & & & 2.87, d (9.7) & & \\
\hline 11 & $3.87, \mathrm{~s}$ & $3.80, \mathrm{~s}$ & $3.80, \mathrm{~s}$ & $3.81, \mathrm{~s}$ & $3.88, \mathrm{~s}$ & $3.82, \mathrm{~s}$ \\
\hline 12 & $1.14, \mathrm{~s}$ & $1.20, \mathrm{~s}$ & $1.20, \mathrm{~s}$ & $1.19, \mathrm{~s}$ & $1.27, \mathrm{~s}$ & $1.21, \mathrm{~s}$ \\
\hline $\mathrm{OH}-2$ & $4.28, \mathrm{~s}$ & $5.69, \mathrm{~s}$ & $5.69, \mathrm{~s}$ & $5.44, \mathrm{~s}$ & $6.24, \mathrm{~s}$ & \\
\hline $\mathrm{OH}-3$ & $4.43, \mathrm{~d}(5.7)$ & & $5.50, \mathrm{~d}(5.3)$ & $4.81, \mathrm{~d}(3.0)$ & $4.91, \mathrm{~s}$ & \\
\hline $\mathrm{OH}-4$ & $5.01, \mathrm{~d}(4.5)$ & & $4.52, \mathrm{~d}(3.5)$ & $4.57, \mathrm{~d}(3.0)$ & $4.96, \mathrm{~s}$ & \\
\hline $\mathrm{OH}-4 \mathrm{a}$ & $6.46, \mathrm{~m}$ & $5.56, \mathrm{~s}$ & $5.57, \mathrm{~s}$ & & & \\
\hline $\mathrm{OH}-5$ & $12.44, \mathrm{~s}$ & $11.97, \mathrm{~s}$ & $11.97, \mathrm{~s}$ & $12.37, \mathrm{~s}$ & $11.15, \mathrm{~s}$ & $12.19, \mathrm{~s}$ \\
\hline OH-1a & & $5.29, \mathrm{~s}$ & $5.29, \mathrm{~s}$ & $4.91, \mathrm{~s}$ & $6.97, \mathrm{~s}$ & \\
\hline OH-9 & & & $5.30, \mathrm{~d}(9.5)$ & $5.46, \mathrm{~d}(8.7)$ & & \\
\hline
\end{tabular}

${ }^{\mathrm{a}}$ in $\mathrm{DMSO}{ }^{\mathrm{b}}$ in $\mathrm{CDCl}_{3}$

Table 2. ${ }^{13} \mathrm{C}$ NMR data of compounds 1-7 (125 MHz, DMSO, TMS, $\delta$ ppm).

\begin{tabular}{cccccc}
\hline No. & $\mathbf{1}$ & $\mathbf{2}$ & $\mathbf{3}$ & $\mathbf{4}$ & $\mathbf{5}$ \\
\hline 1 & $34.2, \mathrm{CH}_{2}$ & $34.3, \mathrm{CH}_{2}$ & $38.7, \mathrm{CH}_{2}$ & $30.7, \mathrm{CH}_{2}$ & $42.4, \mathrm{CH}_{2}$ \\
2 & $72.3, \mathrm{C}$ & $73.5, \mathrm{C}$ & $73.2, \mathrm{C}$ & $73.6, \mathrm{C}$ & $70.3, \mathrm{C}$ \\
3 & $73.7, \mathrm{CH}$ & $76.9, \mathrm{CH}$ & $75.2, \mathrm{CH}$ & $75.7, \mathrm{CH}$ & $72.9, \mathrm{CH}$ \\
4 & $71.3, \mathrm{CH}$ & $64.6, \mathrm{CH}$ & $66.1, \mathrm{CH}$ & $63.5, \mathrm{CH}$ & $65.2, \mathrm{CH}$ \\
5 & $166.1, \mathrm{C}$ & $164.8, \mathrm{C}$ & $163.8, \mathrm{C}$ & $163.6, \mathrm{C}$ & $164.9, \mathrm{C}$ \\
6 & $106.1, \mathrm{CH}$ & $99.7, \mathrm{CH}$ & $99.5, \mathrm{CH}$ & $107.2, \mathrm{CH}$ & $100.1, \mathrm{CH}$ \\
7 & $166.3, \mathrm{C}$ & $166.4, \mathrm{C}$ & $166.3, \mathrm{C}$ & $165.7, \mathrm{C}$ & $166.8, \mathrm{C}$ \\
8 & $105.0, \mathrm{CH}$ & $106.2, \mathrm{CH}$ & $105.8, \mathrm{CH}$ & $106.4, \mathrm{CH}$ & $106.6, \mathrm{CH}$ \\
9 & $197.3, \mathrm{C}$ & $70.0, \mathrm{CH}$ & $73.9, \mathrm{CH}$ & $190.6, \mathrm{C}$ & $68.6, \mathrm{CH}$ \\
10 & $200.1, \mathrm{C}$ & $202.4, \mathrm{C}$ & $206.0, \mathrm{C}$ & $194.4, \mathrm{C}$ & $196.6, \mathrm{C}$ \\
$1 \mathrm{a}$ & $48.0, \mathrm{CH}$ & $79.3, \mathrm{C}$ & $78.5, \mathrm{C}$ & $80.5, \mathrm{C}$ & $64.8, \mathrm{C}$ \\
$4 \mathrm{a}$ & $78.2, \mathrm{C}$ & $78.1, \mathrm{C}$ & $53.3, \mathrm{CH}$ & $72.1, \mathrm{C}$ & $63.3, \mathrm{C}$ \\
$9 \mathrm{a}$ & $137.6, \mathrm{C}$ & $148.4, \mathrm{C}$ & $149.0, \mathrm{C}$ & $134.5, \mathrm{C}$ & $145.9, \mathrm{C}$ \\
$10 \mathrm{a}$ & $110.1, \mathrm{C}$ & $108.6, \mathrm{C}$ & $110.8, \mathrm{C}$ & $110.0, \mathrm{C}$ & $107.1, \mathrm{C}$ \\
11 & $56.7, \mathrm{CH} 3$ & $56.1, \mathrm{CH}_{3}$ & $56.1, \mathrm{CH}_{3}$ & $56.7, \mathrm{CH}_{3}$ & $56.2, \mathrm{CH}$ \\
12 & $23.1, \mathrm{CH}$ & $27.6, \mathrm{CH}_{3}$ & $27.8, \mathrm{CH}_{3}$ & $27.6, \mathrm{CH}_{3}$ & $26.1, \mathrm{CH}_{3}$ \\
\hline
\end{tabular}
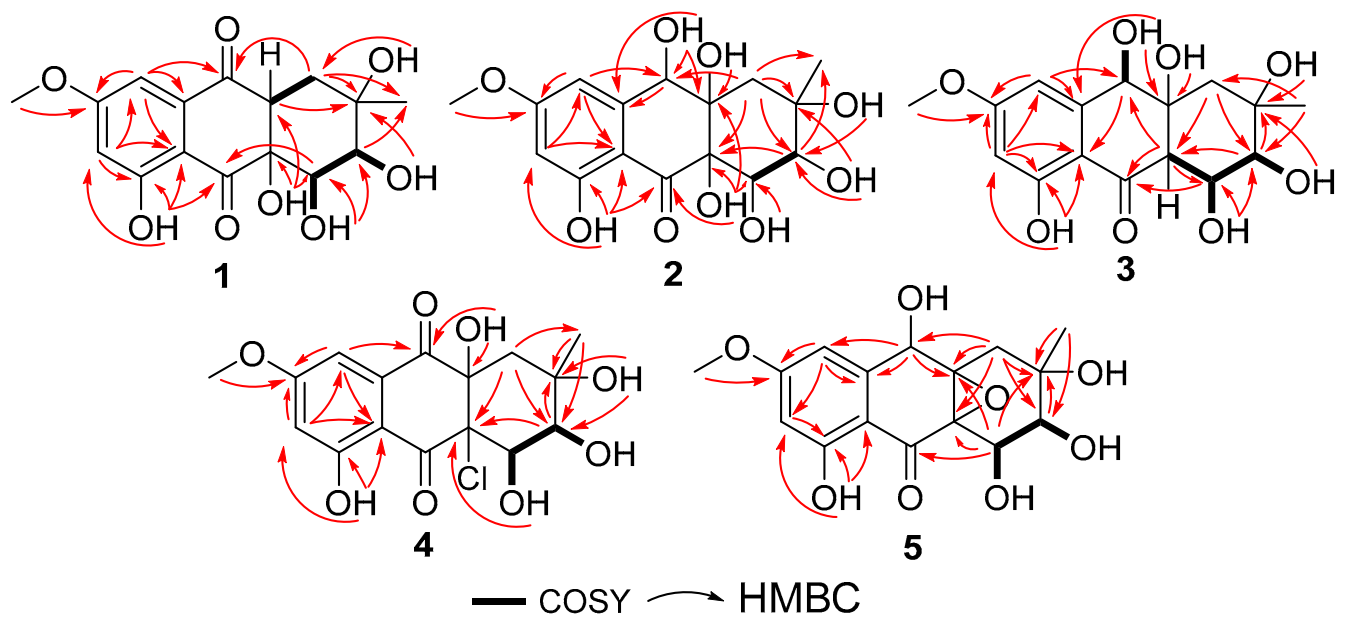

Figure 2. Key HMBC and ${ }^{1} \mathrm{H}^{-1} \mathrm{H}$ COSY correlations of 1-5. 
The relative configuration of the stereogenic carbons in $\mathbf{1}$ was detected by NOESY correlations and conformational analysis (Figure 3 and Figure S7). The NOESY correlations from H-3 to H-1a and 4a-OH, from $\mathrm{H}-1 \mathrm{a}$ to $\mathrm{H}-4$, and from $\mathrm{H}-4$ to $4 \mathrm{a}-\mathrm{OH}$ indicated that $\mathrm{H}-1 \mathrm{a}$ and $4 \mathrm{a}-\mathrm{OH}$ were located on the same face of the molecule, which meant that the $\mathrm{B}$ ring and $\mathrm{C}$ ring were cis fused. The NOESY correlations from $\mathrm{H}-1 \mathrm{a}$ and $\mathrm{H}-4$ to $\mathrm{H}_{3}-12$ oriented $\mathrm{H}_{3}-12$ to the same side as $\mathrm{H}-1 \mathrm{a}$ and $\mathrm{H}-4$. Computational simulation by Chemdraw (Minimize Energy program), together with the small $J$ coupling constant between H-3 and $\mathrm{H}-4\left({ }^{3} \mathrm{~J}_{\mathrm{H}-3, \mathrm{H}-4}=3.1 \mathrm{~Hz}\right)$, further confirmed the chair-chair conformation for rings $\mathrm{B}$ and $\mathrm{C}$, where $\mathrm{H}-1 \mathrm{a}$ (ax), $\mathrm{H}-3$ (eq), $\mathrm{H}-4$ (ax), 4a-OH (eq), and $\mathrm{H}_{3}-12$ (ax) were oriented on the same face, thus completing the relative configuration of the stereogenic carbons in $\mathbf{1}$ (Figure 3). To determine the absolute configuration of compound $\mathbf{1}$, the theoretical calculated electronic circular dichroism (ECD) spectra of possible models were performed using TDDFT. The optimized conformation of the model was obtained and further used for the ECD calculation at the B3LYP/6-31+G(d) level. The pattern (2S, $3 R, 4 S, 1 \mathrm{a} R, 4 \mathrm{a} S)-1$ of the calculated ECD spectrum was in reasonable agreement with the experimental ECD spectra (Figure 4). Thus, the absolute configuration of 1 was established as $2 S, 3 R, 4 S, 1 \mathrm{a} R, 4 \mathrm{a} S$, and we named it auxarthrol D.

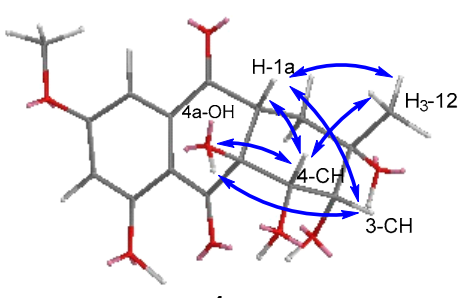

1

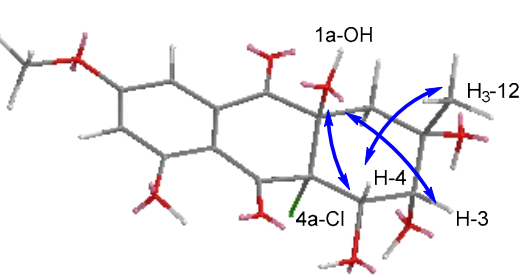

4

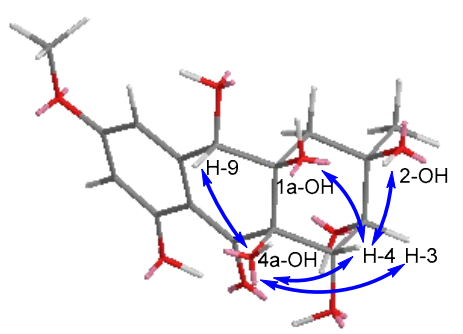

2

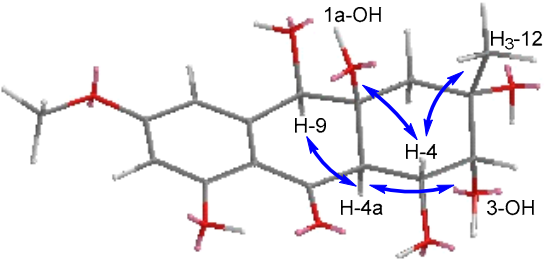

3

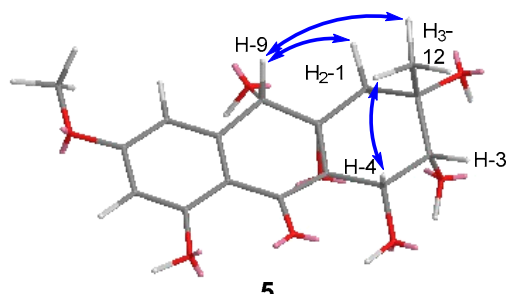

5

Figure 3. Key NOE correlations of 1-5.
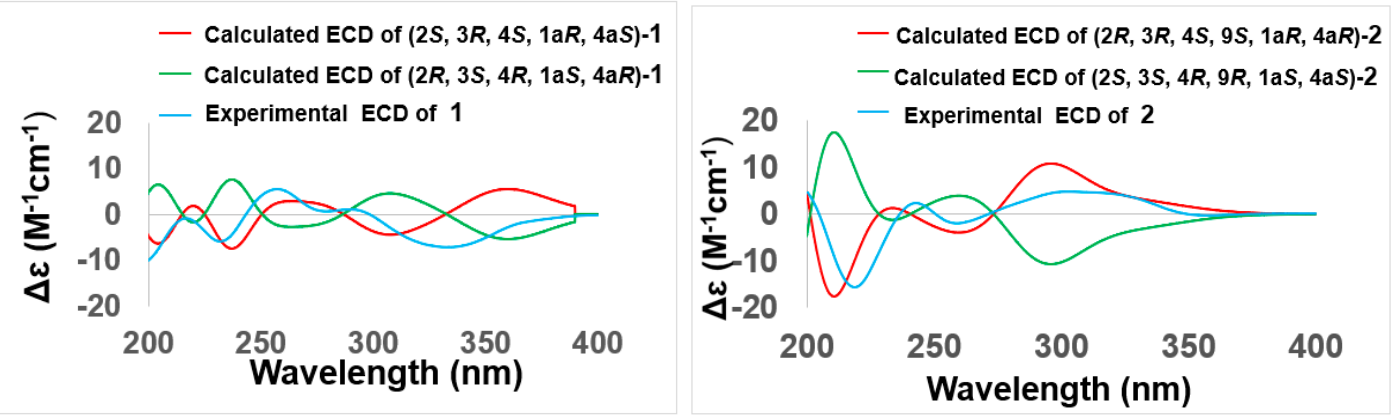

Figure 4. Comparison of the calculated and experimental ECD spectra of 1-2, auxarthrols D-E.

Compound 2 was obtained as a pale yellow powder. Its molecular formula of $\mathrm{C}_{16} \mathrm{H}_{20} \mathrm{O}_{9}$ with seven degrees of unsaturation was determined by the ion peak $m / z 341.1237[\mathrm{M}+\mathrm{H}]^{+}$in the $(+)-$HRESIMS. The molecular formula was also corroborated by exploiting ${ }^{1} \mathrm{H}$ and ${ }^{13} \mathrm{C}$ NMR spectroscopic data (Tables 1 and 2 and Supplementary Materials). A comparison of these data with 1 revealed the same skeleton with different substitutions. The upfield shift of C-9 $\left(\delta_{C} 69.0\right.$ Vs. $\left.\delta_{C} 197.3\right)$ and the downfield shift of C-1a $\left(\delta_{C} 79.3\right.$ Vs. $\left.\delta_{C} 48.0\right)$ indicated that both of the C-9 and C-1a positions were substituted by a hydroxyl group in 2 (Table 2). Key HMBC correlations from H-9 to C-9, C-8, and C-1; from 1a-OH to 
C-1a and C-1; and from 9-OH to C-9 and C-9a (Figure 2 and Supplementary Materials) confirmed the locations of C-9 and C-1a hydroxyl groups, thus completing the planar structure of 2 . The relative configurations of the stereogenic carbons were determined by NOESY correlations and $J$ coupling constant analysis (Table 1, Figure 3 and Supplementary Materials). The NOESY correlations from H-4 to both $1 \mathrm{a}-\mathrm{OH}$ and $4 \mathrm{a}-\mathrm{OH}$ and from $\mathrm{H}-3$ to $4 \mathrm{a}-\mathrm{OH}$, together with the small $\mathrm{J}$ coupling constant between $\mathrm{H}-3$ and $\mathrm{H}-4\left({ }^{3} J_{\mathrm{H}-3, \mathrm{H}-4}=3.0 \mathrm{~Hz}\right)$, indicated that $1 \mathrm{a}-\mathrm{OH}, 4 \mathrm{a}-\mathrm{OH}, \mathrm{H}-3$, and $\mathrm{H}-4$ were located on the same face. Other NOE correlations from $\mathrm{H}-3$ to $\mathrm{H}_{3}-12$ and 2-OH and from $\mathrm{H}-4$ to 2-OH with the above evidence suggested a chair conformation of the $\mathrm{C}$ ring, where $\mathrm{H}-3$ (eq), $\mathrm{H}-4$ (ax), and 2-OH (ax) were on the same face, while $\mathrm{H}_{3}-12$ (eq) was oriented on the opposite face of the molecule. This conformation was further confirmed by using Chemdraw Minimize Energy simulation. Further NOESY correlation from $\mathrm{H}-9$ to $4 \mathrm{a}-\mathrm{OH}$ indicated that $\mathrm{H}-9$ was on the same face as 4a-OH (Figure 3), thus providing the relative configuration of the stereogenic carbons of $\mathbf{2}$. The absolute configuration of $\mathbf{2}$ was determined by comparing the experimental and calculated ECD spectrum using time-dependent density-functional theory (TDDFT). The good agreement of the calculated ECD spectrum of $(2 R, 3 R, 4 S, 9 S, 1 \mathrm{a} R, 4 \mathrm{a} R)-2$ with that of the experimental spectrum (Figure 4) suggested that the absolute configuration of 2 was $2 R, 3 R, 4 S, 9 S, 1 \mathrm{a} R, 4 \mathrm{a} R$, and we named it auxarthrol $\mathrm{E}$.

Compound $\mathbf{3}$ was obtained as a pale yellow powder. The molecular formula of $\mathbf{3}$ was deduced as $\mathrm{C}_{16} \mathrm{H}_{20} \mathrm{O}_{9}$ (seven degrees of unsaturation) by (+)-HRESIMS $\mathrm{m} / z 357.1187[\mathrm{M}+\mathrm{H}]^{+}$, which was also corroborated by ${ }^{1} \mathrm{H}$ and ${ }^{13} \mathrm{C}$ NMR spectroscopic data, as shown in Tables 1 and 2, which was 16 amu more than the molecular mass of compound 2, therefore revealing a close relationship between 3 and 2. According to $1 \mathrm{D}$ NMR spectra, the presence of a methine signal at $2.87 \mathrm{ppm}$ and the absence of a hydroxy group in 3 along with the upfield shift of C-4a $\left(\delta_{C} 53.3\right.$ Vs. $\left.\delta_{C} 78.1\right)$ suggested that the $4 \mathrm{a}-\mathrm{OH}$ in 2 was replaced by a hydrogen atom in 3 (Tables 1 and 2), which was confirmed by the key HMBC correlation from H-4a to C-10 and C-4 (Figure 2 and Supplementary Materials). The relative configurations of the stereogenic carbons were also determined by NOESY correlations and $J$ coupling constant analysis. The NOESY correlations from $\mathrm{H}-9$ to $\mathrm{H}-4 \mathrm{a}$ and the large $J$ coupling constant between $\mathrm{H}-4$ and $\mathrm{H}-4 \mathrm{a}\left({ }^{3} \mathrm{~J}_{\mathrm{H}-4, \mathrm{H}-4 \mathrm{a}}=9.7 \mathrm{~Hz}\right)$ indicated that $\mathrm{H}-4(\mathrm{ax})$ and $1 \mathrm{a}-\mathrm{OH}(\mathrm{ax})$ were on the same face, while $\mathrm{H}-4 \mathrm{a}$ (ax) was located on the opposite face, indicating that the $\mathrm{B}$ ring and $\mathrm{C}$ ring were trans fused. $\mathrm{By}$ using the Minimize Energy simulation programe in Chemdraw, both $B$ and $C$ rings were proposed to adopt a chair conformation, which provided the lowest steric energy. The NOESY correlation from $\mathrm{H}-4$ to $\mathrm{H}_{3}-12$ with the small $J$ coupling constant between $\mathrm{H}-3$ and $\mathrm{H}-4\left({ }^{3} \mathrm{~J}_{\mathrm{H}-3, \mathrm{H}-4}=3.0 \mathrm{~Hz}\right)$ assigned $\mathrm{H}_{3}-12$ and $\mathrm{H}-3$ (eq) on the same face as $\mathrm{H}-4$ (ax) (Figure 3), thus providing the relative configuration of the stereogenic carbons of 3 . The good agreement of the calculated ECD spectrum of $(2 S, 3 R, 4 R, 9 R, 1 \mathrm{a} S$, $4 \mathrm{a} R$ )-3 with that of the experimental spectrum (Figure 5) suggested that the absolute configuration of 3 was $2 S, 3 R, 4 R, 9 R, 1 \mathrm{a} S, 4 \mathrm{a} R$, and we named it auxarthrol $\mathrm{F}$.
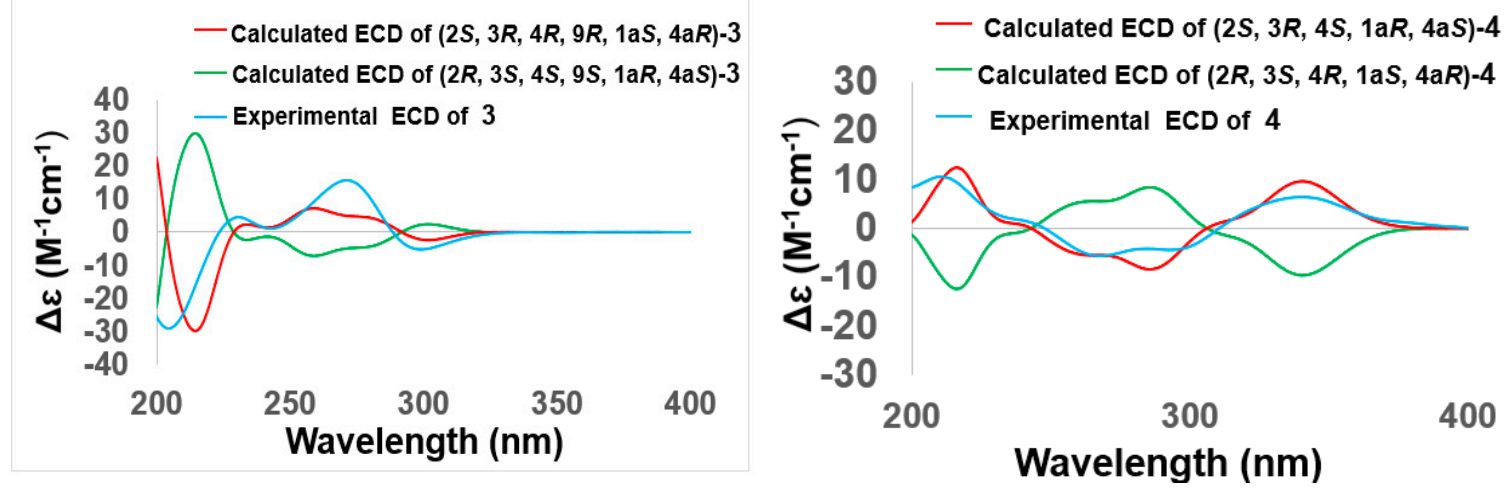

Figure 5. Comparison of the calculated and experimental ECD spectra of 3-4, auxarthrols F-G.

Compound 4 was obtained as a pale yellow powder. Its molecular formula of $\mathrm{C}_{16} \mathrm{H}_{18} \mathrm{ClO}_{8}$ (eight degrees of unsaturation) was determined by (+)-HRESIMS. The molecular formula was also 
corroborated by ${ }^{1} \mathrm{H}$ and ${ }^{13} \mathrm{C}$ NMR spectroscopic data (Tables 1 and 2), suggesting that the structure of 4 resembled that of paradictyoarthrin A (8) [16], except for the absence of the hydroxyl group on C-9 and the presence of a keto-carbonyl signal at $\delta_{C}$ 190.6, indicating that the C-9 hydroxyl was replaced by a ketone. Further 2D NMR data confirmed the planar structure of 4 (Figure 2 and Supplementary Materials). The relative configurations of the stereogenic carbons of 4 were established by NOESY correlations and $J$ coupling constant analysis (Table 1, Figure 3 and Supplementary Materials). The NOESY correlations from $\mathrm{H}-4$ and $\mathrm{H}-3$ to $1 \mathrm{a}-\mathrm{OH}$ indicated that $1 \mathrm{a}-\mathrm{OH}$ and $4 \mathrm{a}-\mathrm{Cl}$ were located on the opposite side of the $\mathrm{B}$ ring, while the NOESY correlation from $\mathrm{H}-4$ to $\mathrm{H}_{3}-12$ with a very small $\mathrm{J}$ coupling constant between $\mathrm{H}-3$ and $\mathrm{H}-4$ suggested that $\mathrm{H}-3$ (eq), $\mathrm{H}-4$ (ax), $\mathrm{H}_{3}-12$ (ax), and 1a-OH (ax) were oriented on the same side of the $C$ ring. Moreover, the calculated ECD spectrum of the model compound $(2 S, 3 R, 4 S, 1 \mathrm{a} R, 4 \mathrm{a} S)-4$ was well-matched with the experimental ECD spectrum of 4 (Figure 5), thus confirming the absolute structure of $\mathbf{4}$, and we named it auxarthrol G.

Compound 5 was obtained as a pale yellow solid, with the molecular formula $\mathrm{C}_{16} \mathrm{H}_{18} \mathrm{O}_{8}$ (eight degrees of unsaturation) from (+)-HRESIMS $m / z 357.1187[\mathrm{M}+\mathrm{H}]^{+}$combined with ${ }^{1} \mathrm{H}$ and ${ }^{13} \mathrm{C}$ NMR spectroscopic data (Tables 1 and 2). A comparison of 1D NMR data with those reported for altersolanol $\mathrm{O}$ [17] revealed a similar hydroanthraquinone skeleton, while the only differences were the absence of C-1 hydroxy and the replacement of the C-9 carbonyl group with a C-9 hydroxyl group in 5, which was further confirmed by the key HMBC correlations from $\mathrm{H}-9$ to C-1a and C-9a, and from $\mathrm{H}_{2}-1$ to C-1a and C-9 (Figure 2 and Supplementary Materials). The relative configuration was also determined by NOESY correlations and $J$ coupling constant analysis. The NOESY correlations from $\mathrm{H}-9$ to $\mathrm{H}_{3}-12$ and $\mathrm{H}_{2}-1$ indicated that $\mathrm{H}-9$ (ax) and $\mathrm{H}_{3}-12$ (ax) were on the same face, showing that the $\mathrm{B}$ ring and $\mathrm{C}$ ring were cis fused with the $\mathrm{C}-1 \mathrm{a}$ and $\mathrm{C}-4 \mathrm{a}$ epoxide ring on the opposite side to $\mathrm{H}-9$ (Figure 3). Further NOESY correlations from $\mathrm{H}-4$ to $2-\mathrm{CH}_{3}$ with the small $\mathrm{J}$ coupling constant between $\mathrm{H}-3$ and $\mathrm{H}-4\left({ }^{3} \mathrm{~J}_{\mathrm{H}-3, \mathrm{H}-4}=3.7 \mathrm{~Hz}\right)$ suggested that $\mathrm{H}-3(\mathrm{eq}), \mathrm{H}-4(\mathrm{ax})$, and $\mathrm{H}_{3}-12(\mathrm{ax})$ were on the same face of the $C$ ring. The absolute configurations of the stereogenic carbons of 5 were determined as $2 S, 3 R, 4 S, 1 \mathrm{a} S$, $4 \mathrm{a} S, 9 S$ by a comparison of the experimental and calculated ECD spectra (Figure 6). Compound $\mathbf{5}$ was named auxarthrol $\mathrm{H}$.

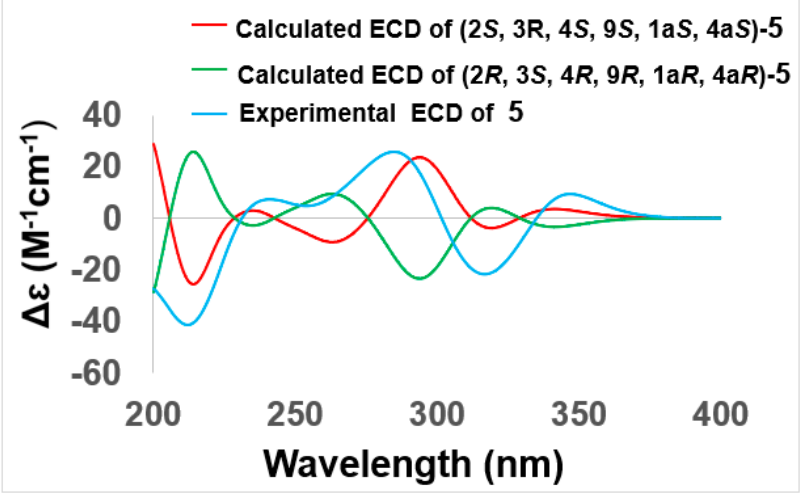

Figure 6. Comparison of the calculated and experimental ECD spectra of 5, auxarthrol $\mathrm{H}$.

By a comparison of the NMR and MS data with the literature, two known compounds were identified as 4-dehydroxyaltersolanol A (6) [14] and altersolanol B (7) [11] (Figure 1).

As a typical class of anthraquinone derivatives, auxarthrols characterized with multiple hydroxyl groups attached on the hydroanthraquinone skeleton were first isolated in 1969 [11] and this was followed by total synthesis and biosynthetic studies [18,19]. By the end of 2018, seventeen altersolanols [19] and three auxarthrols [12,19] had been discovered and because of their broad range of biological activities [20-22], this class of compounds has received growing attention from the natural product community.

Compounds 1-7 were tested for their cytotoxic activity against eleven types of human cancer cell lines using SRB staining [23] and MTT [24] methods, with doxorubicin hydrochloride (Dox) as a 
positive control. Compounds 1 and $\mathbf{3}$ showed moderate cytotoxic activity against eleven human cancer cell lines, with $\mathrm{IC}_{50}$ values ranging from $4.5 \mu \mathrm{M}$ to $22.9 \mu \mathrm{M}$ (Table 3). The antimicrobial activity of 1-7 was also evaluated and 1, 3-4, and 6-7 showed promising antibacterial activity, with MIC values ranging from $12.5 \mu \mathrm{M}$ to $200 \mu \mathrm{M}$. (Table 4).

Table 3. Cytotoxic effect of $\mathbf{1}$ and $\mathbf{3}$ against eleven human cancer cell lines.

\begin{tabular}{cccccccccccc}
\hline \multirow{2}{*}{ Comp. } & \multicolumn{10}{c}{ IC $_{\mathbf{5 0}}(\boldsymbol{\mu M})$} \\
\cline { 2 - 11 } & HL-60 & Hela & HCT-116 & MGC-803 & HO8910 & MDA-MB-231 & SH-SY5Y & PC-3 & BEL-7402 & K562 & L-02 \\
\hline $\mathbf{1}$ & 7.5 & $>50.0$ & 14.5 & 21.8 & $>50.0$ & 19.1 & 22.9 & 21.9 & 16.6 & $>50.0$ & $>50.0$ \\
$\mathbf{3}$ & 4.5 & 10.7 & 7.8 & 17.7 & 18.7 & 10.1 & 17.2 & 20.0 & 21.3 & 16.5 & 22.2 \\
Dox $^{\text {a }}$ & 0.1 & 0.6 & 0.2 & 0.2 & 0.4 & 0.2 & 0.1 & 1.0 & 0.4 & 0.3 & 0.4 \\
\hline
\end{tabular}

${ }^{a}$ Dox stands for doxorubicin hydrochloride, which was used as a positive control.

Table 4. Antimicrobial effect of 1-7 on seven microorganisms.

\begin{tabular}{|c|c|c|c|c|c|c|c|}
\hline \multirow{2}{*}{ Comp. } & \multicolumn{7}{|c|}{$\operatorname{MIC}(\mu \mathrm{M})$} \\
\hline & $\begin{array}{c}\text { Mycobacterium } \\
\text { Phlei }\end{array}$ & $\begin{array}{l}\text { Proteus } \\
\text { Species }\end{array}$ & $\begin{array}{l}\text { Bacillus } \\
\text { subtilis }\end{array}$ & $\begin{array}{l}\text { Candida } \\
\text { albicans }\end{array}$ & $\begin{array}{c}\text { Vibrio } \\
\text { Parahemolyticus }\end{array}$ & $\begin{array}{l}\text { Escherichia } \\
\text { coli }\end{array}$ & $\begin{array}{c}\text { Pseudomonas } \\
\text { aeruginosa }\end{array}$ \\
\hline 1 & 25.0 & 50.0 & 100 & $>200$ & 50.0 & 100 & 50.0 \\
\hline 2 & $>200$ & $>200$ & $>200$ & $>200$ & $>200$ & $>200$ & $>200$ \\
\hline 3 & 200 & 200 & 200 & $>200$ & $>200$ & $>200$ & 200 \\
\hline 4 & 50.0 & 25.0 & 25.0 & 200 & 100 & $>200$ & 100 \\
\hline 5 & $>200$ & $>200$ & $>200$ & $>200$ & $>200$ & $>200$ & $>200$ \\
\hline 6 & 25.0 & 50.0 & 25.0 & $>200$ & 25.0 & $>200$ & 25.0 \\
\hline 7 & 25.0 & 100 & 25.0 & $>200$ & 25.0 & $>200$ & 12.5 \\
\hline $\begin{array}{l}\text { Positive } \\
\text { Control }\end{array}$ & $3.12^{\mathrm{a}}$ & $1.56^{\mathrm{a}}$ & $0.781^{a}$ & $1.56^{\mathrm{b}}$ & $0.781^{a}$ & $0.391^{a}$ & $1.56^{\mathrm{a}}$ \\
\hline
\end{tabular}

Moreover, all the compounds were investigated for their anticoagulant activity using argatroban as a positive control (inhibition ratio: 65.0\%). Compounds 4 and 6 displayed a moderate effect with an inhibition ratio of $47.8 \%$ and $51.5 \%$, respectively (Table 5). In addition, all the compounds were tested for antitubercular activity, but only 7 displayed a weak antitubercular effect, with an MIC value of $20.0 \mu \mathrm{g} / \mathrm{mL}$ (Table 6).

Table 5. Anticoagulant activity of 1-7.

\begin{tabular}{ccccccccc}
\hline Comp. & $\mathbf{1}$ & $\mathbf{2}$ & $\mathbf{3}$ & $\mathbf{4}$ & $\mathbf{5}$ & $\mathbf{6}$ & $\mathbf{7}$ & Argatroban $^{\mathbf{b}}$ \\
\hline Inhibition ratio $^{\text {a }}$ & 12.5 & 19.9 & 14.4 & 47.8 & 27.3 & 51.5 & 19.3 & 65.0 \\
\hline
\end{tabular}

${ }^{a}$ Data are expressed as inhibition ratio values $(\%) ;{ }^{b}$ Argatroban was used as a positive control.

Table 6. Antitubercular activity of 1-7 against AlRa.

\begin{tabular}{ccccccccc}
\hline Comp. & $\mathbf{1}$ & $\mathbf{2}$ & $\mathbf{3}$ & $\mathbf{4}$ & $\mathbf{5}$ & $\mathbf{6}$ & $\mathbf{7}$ & Rifampin $^{\mathbf{b}}$ \\
\hline MIC $^{\mathrm{a}}$ & $>20.0$ & $>20.0$ & $>20.0$ & $>20.0$ & $>20.0$ & $>20.0$ & 20.0 & 1.0 \\
\hline \multicolumn{7}{c}{${ }^{\mathrm{a}}$ Data are expressed as MIC values $(\mu \mathrm{g} / \mathrm{mL}){ }^{\mathrm{b}}$ Rifampin was used as a positive control. }
\end{tabular}

\section{Materials and Methods}

\subsection{General Experimental Procedures}

UV spectra were recorded on Waters 2487. IR spectra were recorded on a Nicolet NEXUS 470 spectrophotometer in KBr discs (Thermo Scientific, Beijing, China). Optical rotations were measured on a JASCO P-1020 digital polarimeter (JASCO Corporation, Tokyo, Japan). HRESIMS and ESIMS data were obtained on a Thermo Scientific LTQ Orbitrap XL mass spectrometer. ECD spectra were measured on a JASCO J-715 spectra polarimeter (JASCO Corporation, Tokyo, Japan). NMR spectra 
were recorded on an Agilent $500 \mathrm{MHz}$ DD2 spectrometer using TMS as the internal standard, and the chemical shifts were recorded as $\delta$ values. Semi-preparative HPLC was performed on an ODS column (HPLC (YMC-Pack ODS-A, $10 \times 250 \mathrm{~mm}, 5 \mu \mathrm{m}, 3 \mathrm{~mL} / \mathrm{min}$ )). MPLC was performed on a Bona-Agela CHEETAHTM HP100 (Beijing Agela Technologies Co., Ltd., Beijing, China). Column chromatography (CC) was performed with silica gel (200-300 mesh, Qingdao Marine Chemical Inc. Qingdao, China) and Sephadex LH-20 (Amersham Biosciences, San Francisco, CA, USA), respectively.

\subsection{Fungal Material}

The fungal strain HDN16-802 was isolated from the sediment sample of Zhangzi Island, collected from Dalian, Liaoning Province, China. The strain was identified as Sporendonema casei based on sequencing of the ITS region (GenBank: MK578184). A voucher specimen strain was prepared on potato dextrose agar slants and deposited at $-20{ }^{\circ} \mathrm{C}$ in the Key Laboratory of Marine Drugs, Chinese Ministry of Education.

\subsection{Fermentation and Extraction}

S. casei HDN16-802 was cultured on slants with PDA at $28^{\circ} \mathrm{C}$ for 7 days. Further fermentation was carried out under static conditions at room temperature for 30 days in Erlenmeyer flasks (1000 mL), with each containing $53 \mathrm{~g}$ of oatmeal and naturally collected seawater (125 mL per flask) from Huiquan Bay, Qingdao, China. The pooled fermentation broth, together with mycelium (total of $45 \mathrm{~L}$ ), were macerated and extracted with an equal volume of EtOAc three times. The organic layers were combined together and concentrated under reduced pressure to yield the extract $(10 \mathrm{~g})$.

\subsection{Isolation}

The extract ( $10 \mathrm{~g}$ ) was fractionated by VLC column chromatography on silica gel using stepwise gradient elution with petroleum ether- $\mathrm{CH}_{2} \mathrm{Cl}_{2}-\mathrm{MeOH}$ (from PE only to PE with DCM in different ratios and DCM only later, and then from DCM only to DCM with $\mathrm{MeOH}$ in different ratios and $\mathrm{MeOH}$ only, depending on the polarity from small to large) to give six fractions (fraction 1 to fraction 6). Fraction 5 (eluted with 92:8 DCM-MeOH) was further separated by MPLC and then HPLC, eluting with $\mathrm{MeOH} / \mathrm{H}_{2} \mathrm{O}(35: 65)$ to obtain $1\left(\mathrm{t}_{\mathrm{R}} 28 \mathrm{~min}\right.$; $10.0 \mathrm{mg}$ ). Fraction 2 (eluted with 98:2 DCM-MeOH) was applied on a Sephadex LH-20 column and eluted with $\mathrm{MeOH}$ to provide six fractions (fraction 2-1 to fraction 2-6). Fraction 2-4 was separated by HPLC eluting with $\mathrm{MeCN} / \mathrm{H}_{2} \mathrm{O}$ (23:77) to obtain 4 $\left(t_{\mathrm{R}} 40 \mathrm{~min} ; 5.0 \mathrm{mg}\right.$ ) and 7 ( $\mathrm{t}_{\mathrm{R}} 35 \mathrm{~min} ; 5.0 \mathrm{mg}$ ). Fraction 3 (eluted with 94:6 DCM-MeOH) was further separated by a C-18 ODS column with a step gradient elution of $\mathrm{MeOH}-\mathrm{H}_{2} \mathrm{O}$ (15:85-80:20), resulting in four fractions (fraction 3-1 to fraction 3-4). Fraction 3-1 was separated by HPLC eluting with $\mathrm{MeCN} / \mathrm{H}_{2} \mathrm{O}$ (gradient 15:85-25:75) to provide $2\left(\mathrm{t}_{\mathrm{R}} 23 \mathrm{~min} ; 2.1 \mathrm{mg}\right), 3\left(\mathrm{t}_{\mathrm{R}} 25 \mathrm{~min} ; 5.1 \mathrm{mg}\right), 5\left(\mathrm{t}_{\mathrm{R}} 45 \mathrm{~min}\right.$; $4.5 \mathrm{mg}$ ), and 6 ( $\mathrm{t}_{\mathrm{R}} 50 \mathrm{~min} ; 10.1 \mathrm{mg}$ ) and Fraction 3-1-3 was further purified by HPLC using $\mathrm{MeOH} / \mathrm{H}_{2} \mathrm{O}$ (24:76) as an eluent to obtain 5 ( $\left.\mathrm{t}_{\mathrm{R}} 25 \mathrm{~min} ; 7.9 \mathrm{mg}\right)$.

Auxarthrol D (1): Pale yellow crystal; $[\alpha]_{\mathrm{D}}^{25}-20.45$ (c 0.03, MeOH); UV (MeOH) $\lambda_{\max }(\log \varepsilon) 248$ (2.4), 295 (1.2), 350 (1.2) nm; CD (2.5 mM, MeOH) $\lambda_{\max }(\Delta \varepsilon) 218(+0.74), 240(-1.78) \mathrm{nm}, 260(+3.13) \mathrm{nm}$, $333(-3.68) \mathrm{nm}$; IR (KBr) $v_{\max } 3366,2940,2360,1700,1636,1615,1385,1305,1204,1164,1102,1032$, $910 \mathrm{~cm}^{-1}$; for ${ }^{1} \mathrm{H}$ and ${ }^{13} \mathrm{C}$ NMR data, see Tables 1 and 2; HRESIMS m/z 339.1076 [M+H] ${ }^{+}$(calculated for $\mathrm{C}_{16} \mathrm{H}_{19} \mathrm{O}_{8}, 339.1074$ )

Auxarthrol E (2): Pale yellow powder; $[\alpha]_{\mathrm{D}}^{25}-19.0$ (c 0.04, MeOH); UV (MeOH) $\lambda_{\max }(\log \varepsilon) 290$ (2.4), 330 (1.6) nm; CD (2.5 mM, MeOH) $\lambda_{\max }(\Delta \varepsilon) 218(-1.74), 240(+0.58) \mathrm{nm}, 300(+3.78) \mathrm{nm} ; \mathrm{IR}(\mathrm{KBr})$ $v_{\max } 3356,2934,2361,1717,1625,1577,1376,1291,1204,1158,1074,851 \mathrm{~cm}^{-1}$; for ${ }^{1} \mathrm{H}$ and ${ }^{13} \mathrm{C} \mathrm{NMR}$ data, see Tables 1 and 2; HRESIMS m/z 357.1187 [M+H] $]^{+}$(calculated for $\mathrm{C}_{16} \mathrm{H}_{21} \mathrm{O}_{9}, 357.1180$ ).

Auxarthrol F (3): Pale yellow powder; $[\alpha]_{\mathrm{D}}^{25}-65.0$ (c 0.2, MeOH); UV (MeOH) $\lambda_{\max }(\log \varepsilon) 280$ (2.4), $340(1.0) \mathrm{nm} ; \mathrm{CD}(2.5 \mathrm{mM}, \mathrm{MeOH}) \lambda_{\max }(\Delta \varepsilon) 218(-1.54) \mathrm{nm}, 240(+0.78) \mathrm{nm}, 300(+3.12) \mathrm{nm}$; IR $(\mathrm{KBr}) v_{\max } 3379,2925,2362,1626,1375,1296,1204,1160,1084,1032,849,780 \mathrm{~cm}^{-1}$; for ${ }^{1} \mathrm{H}$ and ${ }^{13} \mathrm{C}$ NMR data, see Tables 1 and 2; HRESIMS m/z 341.1237 [M+H] $]^{+}$(calculated for $\mathrm{C}_{16} \mathrm{H}_{21} \mathrm{O}_{8}, 347.1231$ ). 
Auxarthrol G (4): Pale yellow powder; $[\alpha]_{\mathrm{D}}^{25}+5.38$ (c 0.08, MeOH); UV (MeOH) $\lambda_{\max }(\log \varepsilon) 245$ (2.4), 300 (1.0), 350 (1.2) nm; CD (2.5 mM, MeOH) $\lambda_{\max }(\Delta \varepsilon) 210(+3.74), 267(-1.78), 333$ (2.73) nm; $\mathrm{IR}(\mathrm{KBr}) \nu_{\max } 3375,2924,2359,1636,1615,1385,1296,1205,1162,1030,771 \mathrm{~cm}^{-1}$; for ${ }^{1} \mathrm{H}$ and ${ }^{13} \mathrm{C}$ NMR data, see Tables 1 and 2; HRESIMS m/z $373.0685[\mathrm{M}+\mathrm{H}]^{+}$(calculated for $\mathrm{C}_{16} \mathrm{H}_{16} \mathrm{O}_{8} \mathrm{Cl}$, 373.0685).

Auxarthrol H (5): Pale yellow powder; $[\alpha]_{\mathrm{D}}^{25}+12.17$ (c 0.2, MeOH); UV (MeOH) $\lambda_{\max }(\log \varepsilon) 274$ (2.4), $315(1.4) \mathrm{nm} ; \mathrm{CD}(2.5 \mathrm{mM}, \mathrm{MeOH}) \lambda_{\max }(\Delta \varepsilon) 218(-1.74), 242(+0.78) \mathrm{nm}, 290(+2.56) \mathrm{nm}, 315$ $(-1.24) \mathrm{nm}, 356(+0.54) \mathrm{nm}$; IR (KBr) $v_{\max } 3356,2933,2361,1627,1376,1298,1205,1159,1103,1024,950$, $601 \mathrm{~cm}^{-1}$; for ${ }^{1} \mathrm{H}$ and ${ }^{13} \mathrm{C}$ NMR data, see Tables 1 and 2; HRESIMS m/z $339.1080[\mathrm{M}+\mathrm{H}]^{+}$(calculated for $\mathrm{C}_{16} \mathrm{H}_{19} \mathrm{O}_{8}$, 339.1074).

\subsection{Assay of Cytotoxic Activity}

Cytotoxic activity was evaluated as previously reported [25].

\subsection{Assay of Antimicrobial Activity}

Antimicrobial activity was evaluated as previously reported [26].

\subsection{Assay of Anticoagulant Activity}

Anticoagulant activity was evaluated as previously reported [27].

\subsection{Assay of Antitubercular Activity}

Antitubercular activity was evaluated as previously reported [28].

\section{Conclusions}

In conclusion, we reported the isolation and structural elucidation of five new bioactive anthraquinone derivatives (1-5), together with two known analogues (6-7), from Sporendonema casei. Compound 4 is the second anthraquinone derivative with a chlorine atom. Compounds $\mathbf{1 - 7}$ were evaluated for their cytotoxic, antimicrobial, anticoagulant, and antitubercular activity. Compounds 1 and 3 showed cytotoxic activities against eleven human cancer cell lines, with $\mathrm{IC}_{50}$ values ranging from $4.5 \mu \mathrm{M}$ to $22.9 \mu \mathrm{M}$, while 1, 3-4, and 6-7 showed promising antibacterial activity, with MIC values ranging from $12.5 \mu \mathrm{M}$ to $200 \mu \mathrm{M}$. Compounds 4 and 6 displayed a moderate anticoagulant effect, which are the first anthraquinone derivatives with this activity. In addition, 7 was found to display potential antitubercular activity.

Supplementary Materials: The following are available online at http://www.mdpi.com/1660-3397/17/6/334/s1, 1D and 2D NMR and HRESIMS spectra of 1-7. Figures S1-S8: 1D and 2D NMR and HRESIMS spectra of Auxarthrol D (1); Figures S9-S17: 1D and 2D NMR and HRESIMS spectra of Auxarthrol E (2); Figures S18-S25: 1D and 2D NMR and HRESIMS spectra of Auxarthrol F (3); Figures S26-S33: 1D and 2D NMR and HRESIMS spectra of Auxarthrol G (4); Figures S34-S41: 1D and 2D NMR and HRESIMS spectra of Auxarthrol H (5).

Author Contributions: The contributions of the respective authors are as follows: X.G. drafted the work and performed the fermentation and extraction, as well as the isolation. X.G. and C.S. elucidated the constituents. Y.F. and L.W. were involved in the biological evaluations. J.P., Q.C., Q.G., T.Z., and D.L. contributed to checking and confirming all of the procedures of the isolation and identification. G.Z. designed the study, supervised the laboratory work, and contributed to the critical reading of the manuscript, and was also involved in structural determination and bioactivity elucidation. All the authors have read the final manuscript and approved the submission.

Funding: This work was financially supported by the National Natural Science Foundation of China (41806167, 41606166), the Marine S\&T Fund of Shandong Province for the Pilot National Laboratory for Marine Science and Technology (Qingdao) (No. 2018SDKJ0401-2), the Fundamental Research Funds for the Central Universities (201941001), and the Taishan Scholar Youth Expert Program in Shandong Province (tsqn201812021).

Conflicts of Interest: The authors declare no conflict of interest. 


\section{References}

1. Zhou, Y.X.; Xia, W.; Yue, W.; Peng, C.; Rahman, K.; Zhang, H.; Evid, J. Rhein: A Review of Pharmacological Activities. Based Complement. Alternat. Med. 2015, 1-10. [CrossRef] [PubMed]

2. Abu, N.; Ali, N.; Ho, W.; Yeap, S.; Aziz, M.Y.; Alitheen, N. Damnacanthal: A Promising Compound as a Medicinal Anthraquinone. Anticancer Agents Med. Chem. 2014, 14, 750-755. [CrossRef] [PubMed]

3. Zheng, C.J.; Shao, C.L.; Guo, Z.Y.; Chen, J.F.; Deng, D.S.; Yang, K.L.; Chen, Y.Y.; Fu, X.M.; She, Z.G.; Lin, Y.C.; Wang, C.Y. Bioactive hydroanthraquinones and anthraquinone dimers from a soft coral-derived Alternaria sp. fungus. J. Nat. Prod. 2012, 75, 189-197. [CrossRef] [PubMed]

4. Kanamaru, S.; Honma, M.; Murakami, T.; Tsushima, T.; Kudo, S.; Tanaka, K.; Nihei, K.; Nehira, T.; Hashimoto, M. Absolute stereochemistry of altersolanol A and alterporriols. Chirality. 2012, 24, 137-146. [CrossRef] [PubMed]

5. Suemitsu, R.; Kitagawa, N.; Horie, S.; Kazawa, K.; Harada, T. Isolation and Identification of Altersolanol B (7-Methoxy-2-methyl-(2R, 3S)-1, 2, 3, 4-tetrahydro-2, 3, 5-trihydroxyanthraquinone) from the Mycelium of Alternaría porri (Ellis) Ciferri. Agric. Biol. Chem. 2014, 42, 1801-1802. [CrossRef]

6. Kasai, M.; Shirahata, K.; Ishii, S.; Mineura, K.; Marumo, H.; Tanaka, H.; OMURA, S. Structure of Nanaomycin E, A New Naaomycin. J. Antibiot. 1979, 5, 442-445. [CrossRef]

7. Okabe, T.; Nomoto, K.; Tanaka, N. Lactoquinomycin B, A Novel Antibiotic. J Antibiot. 1986, 1, 1-5. [CrossRef]

8. Becker, A.M.; Rickards, R.W.; Schmalzl, K.J.; Yick, H.C. Metabolites of Dactylaria Lutea, the Structures of Dactylariol and the Antiprotozoal Antibiotic Dactylarin. J. Antibiot. 1978, 4, 324-329. [CrossRef]

9. Noda, T.; Take, T.; Watanabe, T.; Abe, J. The Structure of Bostrycin. Tetrahedron 1970, 26, 1339-1346. [CrossRef]

10. Debbab, A.; Aly, A.H.; Edrada-Ebel, R.A.; Wray, V.; Müller, W.E.G.; Totzke, F.; Zirrgiebel, U.; Schächtele, C.; Kubbutat, M.H.G.; Lin, W.H.; et al. Bioactive Metabolites from the Endophytic Fungus Stemphylium globuliferum Isolated from Mentha pulegium. J. Nat. Prod. 2009, 72, 626-631. [CrossRef]

11. Ge, H.M.; Song, Y.C.; Shan, C.Y.; Ye, Y.H.; Tan, R.X. New and cytotoxic anthraquinones from Pleospora sp. IFB-E006, an endophytic fungus in Imperata cylindrical. Planta. Med. 2005, 71, 1063-1065. [CrossRef]

12. Alvi, K.A.; Rabenstein, J. Auxarthrol A and auxarthrol B: two new tetrahydoanthraquinones from Auxarthron umbrinum. J. Ind. Microbiol. Biotechnol. 2004, 31, 11-15. [CrossRef]

13. Aly, A.H.; Edrada-Ebel, R.; Wray, V.; Müller, W.E.; Kozytska, S.; Hentschel, U.; Proksch, P.; Ebel, R. Bioactive metabolites from the endophytic fungus Ampelomyces sp. isolated from the medicinal plant Urospermum picroides. Phytochemistry 2008, 69, 1716-1725. [CrossRef] [PubMed]

14. Uzor, P.F.; Ebrahim, W.; Osadebe, P.O.; Nwodo, J.N.; Okoye, F.B.; Muller, W.E.; Lin, W.; Liu, Z.; Proksch, P. Metabolites from Combretum dolichopetalum and its associated endophytic fungus Nigrospora oryzae-Evidence for a metabolic partnership. Fitoterapia 2015, 105, 147-150. [CrossRef]

15. Klaiklay, S.; Rukachaisirikul, V.; Phongpaichit, S.; Pakawatchai, C.; Saithong, S.; Buatong, J.; Preedanon, S.; Sakayaroj, J. Anthraquinone derivatives from the mangrove-derived fungus Phomopsis sp. PSU-MA214. Phytochem. Lett. 2012, 5, 738-742. [CrossRef]

16. Isaka, M.; Chinthanom, P.; Rachtawee, P.; Srichomthong, K.; Srikitikulchai, P.; Kongsaeree, P.; Prabpai, S. Cytotoxic hydroanthraquinones from the mangrove-derived fungus Paradictyoarthrinium diffractum BCC 8704. J. Antibiot (Tokyo) 2015, 68, 334-338. [CrossRef] [PubMed]

17. Chen, B.; Shen, Q.; Zhu, X.; Lin, Y.C. The Anthraquinone Derivatives from the Fungus Alternaria sp. XZSBG-1 from the Saline Lake in Bange, Tibet, China. Molecules 2014, 19, 16529-16542. [CrossRef]

18. Kelly, T.R.; Montury, M. A Regiochemically-controlled Synthesis of Altersolanol B. Tetrahedron. Lett. 1978, 45, 4309-4310. [CrossRef]

19. Locatelli, M. Anthraquinones: Analytical Techniques as a Novel Tool to Investigate on the Triggering of Biological Targets. Curr. Drug. Targets. 2011, 12, 366-380. [CrossRef]

20. Liu, P.; Wang, P.M.; Xu, J.Z. Assignment of NMR Data of Alterporriol I. Chem. Nat. Comp. 2017, 53, 653-657.

21. Pretsch, A.; Proksch, P.; Debbab, A. New Anthraquinone Derivatives. U.S. Patent 0129927 Al, 24 May 2012.

22. Bai, H.; Kong, W.W.; Shao, C.L.; Li, Y.; Liu, Y.Z.; Liu, M.; Guan, F.F.; Wang, C.Y. Zebrafish Embryo Toxicity Microscale Model for Ichthyotoxicity Evaluation of Marine Natural Products. Mar. Biotechnol. (NY) 2016, 18, 264-270. [CrossRef] [PubMed]

23. Mosmann, T. Rapid Colorimetric Assay for Cellular Growth and Survival: Application to Proliferation and Cytotoxicity Assays. J. Immunol. Meth. 1983, 65, 55-63. [CrossRef] 
24. Skehan, P.; Storeng, R.; Scudiero, D.; Monks, A.; Mahon, J.M.; Vistica, D.; Warren, J.T.; Bokesch, H.; Kenney, S.; Boyd, M.R. New Colorimetric Cytotoxicity Assay for Anticancer-Drug Screening. J. Natl. Cancer. Inst. 1990, 82, 1107-1112. [CrossRef]

25. Yu, G.H.; Wu, G.W.; Sun, Z.C.; Zhang, X.M.; Che, Q.; Gu, Q.Q.; Zhu, T.J.; Li, D.H.; Zhang, G.J. Cytotoxic Tetrahydroxanthone Dimers from the Mangrove-Associated Fungus Aspergillus versicolor HDN1009. Mar. Drugs 2018, 16, 335. [CrossRef] [PubMed]

26. Du, L.; Zhu, T.J.; Liu, H.B.; Fang, Y.C.; Zhu, W.M.; Gu, Q.Q. Cytotoxic polyketides from a marine-derived fungus, Aspergillus glaucus. J. Nat. Prod. 2008, 71, 1837-1842. [CrossRef] [PubMed]

27. Xu, Z.; Liu, R.N.; Guan, H.S. Dual-target inhibitor screening against thrombin and factor Xa simultaneously by mass spectrometry. Anal. Chim. Acta 2017, 1-10. [CrossRef] [PubMed]

28. Tang, J.; Wang, B.X.; Wu, T.; Wan, J.T.; Tu, Z.C.; Njire, M.; Wan, B.J.; Franzblauc, S.G.; Zhang, T.Y.; Lu, X.Y.; et al. Design, Synthesis, and Biological Evaluation of Pyrazolo [1,5-a] pyridine-3-carboxamides as Novel Antitubercular Agents. ACS Med. Chem. Lett. 2015, 6, 814-818. [CrossRef]

C 2019 by the authors. Licensee MDPI, Basel, Switzerland. This article is an open access article distributed under the terms and conditions of the Creative Commons Attribution (CC BY) license (http://creativecommons.org/licenses/by/4.0/). 